the Medico-Chirurgical Sosiety of this town, and described the good effects which had resulted from it in my own case, it is only, for reasons which it is unnecessary to mention, within the last few weelcs that I have recommended it to patients; but in every case in which this has been done, the result has been most gratifying and satisfactory. I am, therefore, encouraged -believing, as I do, that anything that could contribute to the prophylaxis of consumption would be gladly hailed and put to the test by the profession-to ask you to gire this note a place in your colnmis.

I am, Sir, your obedient servant,

Aberdeen, Oetober, 1 eco.

WM. Frasen, M. P. C.S. ENG.

THE MARSHATL IIAL METHOD OF TREATMENT IN ASPHYXIA.

To the Editor of THE LANCET.

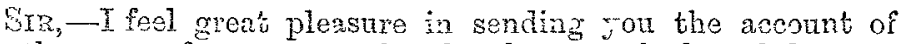
ais: her case of recorery under the shove methor, and do so as a duty, thinking that the preatest tablet to the memory of our inest men will be that long column inscribed with a happy chrowicle of the mach good dono by their original and philoso. phival ideas.

On Pesday, the 9th inst., Mrs. T- was delivered by my pertner and inyself after a lingering and protracted labone. The child was born to ail assearace dead, but after assidu orsly employing the prone and posural rethod for about twenty-five minute;, we wro dolightor to observe the signs of returning life, and the child is no:v strong and healthy.

Trusting yon will agree with me in thinlaing that by every one recording his sucess he will thus be acknowledging the services of the late great farshall Hall, and that you will accorlingly deem this worthy of insertion in your jonrnal,

I am, Sir, yours obediently,

Tcst Jalling, Oct. 1330 .

Samuiz Pralt, M.R.C.S.

\section{THE PHILOSOPHY OF FEVER.}

(FrOAL A CORRZSTONDRNIY)

IT is stated on good authority that a soldier, when complote in evay respoct, costs the conntry $£ 500$. How many of thess ara leept uo is beside ny present purposs to inquire; but the fuct is eaough by irself to show whas a costly article a soldier is, and the importance which must ever belong to bis efficient minterance snd health. He is exposed to most, if not all, the disenges to whioh flesh is heir, and paricularly to those infuences which senerate the class of diseases kiown as fevers. It has been establis'ed that the period of life during which those afiections previl most is the very period when the col dier is most effective. His duries, too, tale him to countries where fever prevails to a degree and intensity unknown amonest ourselves, and hence no year passes in which accennts do not reach us of catbreaks of the disease, and consequent loss of life. Leaving the suldier, however, out of the question, the community at large are deeply interested in the subject. It is true that, within the last wro or three years, fever has prevalled to a very slight axtont, I believe I may say over Great Britain cenerally. Bnt are we then to reckon ourselves free of it? Or is it so very long since an epiclemic of a severe character broke out in the wery neighbourhood of Royalty itself?

How does fever originate? By contagion, some will say; others, by overcrowding, and living in close and bauly-ventilatel awellings; others, by famine; whilst a fourth party attribate to ill-constructed sewerare the outbreaks of the dis ease. Now, I admit that these all, excepting the inrst, which is a direct cause, are capable of predisposing to the disease; lout $w$ hilst doing so, I consider that looking upon them other than as predisposing causes is going further than facts will warrant. I will take the sewerage question as an example of what I mean, because it has been the fashion of late to attribute to this cause more than I think it is entitled to, and, if I mistake not, several writers have set it down as a direct cause of fever, and even of cholera. A case or cases of one or other disease appears, and forth with a sewer is discovered, and at once blamed for the occurrence, whilst it seems taken for granted thit it is the whole cause. There must surely be some inaccu446 rate reasoning here. The sewer had existed for years previously, and yet no fever had appeared. That is, in other words, the cause was there, but not the result. Trifling as this point appears, I believe it to be one of very great moment; and when correct views come to be hell on it, $I$ consider that a step in the right direction will have been gained.

I have glanced at some, and only some, of the predisposing canses of fever. There is one, however, to which $I$ do not venture to give a name, as to the class to which it belongs; and yet it is one which, it strikes me, is of ten overlooked, if, indeed, it be thought of at all. I speak of the disease as being generated within the individuals theinselves. Some, $I$ have no donbt, will question the possibility of such an ocenrence; but there seem to be, or rather there are, some facts which go fur to establish the idea. Thus I may mention what occurs in puerperal fever. Here there is every reason to suppose the diseaze oriminates within the individuals thenselves. Again, can there be any doubt of the caus? of the secondary fever of small-pox? Is the disease known as ty phoid prenmonia other than pneumoni. to which typhus fever is stmeradded? For it is mitter of observation that, at the first so-oni, the ferer is often not of the typhus type. In suruical cases, too, the same order of events is to be observed. A man breaks the neek of his thighbone, and in the course of a week on ten days exhibits all the signs of typins fever, of which he dies. Or a case of anthrar is going on to all appenrance well, when saddenly the fever becomes typhoid, and the patient is rapidly carried off. The same occurs sometimes in the progress of suppuration burns, or $^{\circ}$ erysipelas, or afser amputations or other surgical operations. There is, in point of fact, ample proof that any shock to the system may be followed by iever, and this must have oriomated fron within. This is a causs of the disease which, I think, shonld never be forgotten; though I cannot just now call to mind a single writer who has dwelt on it. Fron this idea some rery important conclasions, as I imagine, f.llow. In the first place, it is clear that, under at least many circumstances, it will be necessary to pay strict attention to the state of the constitution, and this with the direct object of preventing fever. Thus, knowing that, in the puerperal state, or with cases where there is a large suppurating surfuce, or witer opepations, fever may arise, I think the physician or surgeon is bound to try and prevent it. I do not stop here to indicate the best means for this parpose, but only to suggest the idea. Onee this is got and set clealy forth, good results, I consider, must arise; and where the tendency to puerperal fever exists, I have no doubt benefit will ensue from actirg on the ilea.

It may be ulserved, in passing, that, in a somewhat different point of view, the irlea has been carried ont; I mean the prevention of fevers. Thus, in some of our colonies, where fever is ever rife, as the west const of Africa, it has been, of late, the habit to give the healthy men fixed though small doses of quinine daily, and the results have heen of a very satisfactory nature. Now this winciple it is which I would wish to see mere generally adopted amongst oursolves, and for the reasons already given; for I have ever thought that lecitimate reasoning-particulivly when there are facts to go on-is amongist the very best ways of advanoine medicine.

A second conclusion which follows the recognition of the fact that fever may oriminate from causes within the individual, is that it affords some explanation of the varieties which fever presents, and is ever presenting. It is scarcely in the nature of things bat that an arfection like fever must take its hue-if I may so sueak-from the constivation through which it is passing. In many cases this is very obvions. Thus drinking habits notorionsly modify a fever, Again, the disense is even more serious, man for man, anongst the middle and upper ranks than the lower. Different reasons have been advanced for this. The most conclusive appears to me to be the much greater employment of the mind in the one grade than in the other. Again, the temperments change fever; nor do I know a more important principle in the treatment of the disease than ascertaining, as fir as may be, the temperament or peculiar constitution of the case with which we have to deal.

I have said that fever exhibits varieties, some more and others less marked; and the vast number of works published on the subject prove this. But how, then, are we to read, or rather understand them? Is it because these varieties have received different names that we must therefore consider them different fevers, and arising from different poisons? I am aware of the difficulty which surrounds this part of the subject; and particularly the question of the identity of typhus and typhoid fevers, about which so much has, within these few years, been advanced. For myself, I will not venture to give any decided opinion on the point. So long as the impression prevailed 